\title{
Introduction to Jubilee Edition
}

According to Psalm 9o:10, seventy years corresponds to the normal human lifespan. But the seventieth year is also, according to Jeremiah's famous prophecy (Jer 25:11-12), a time of renewal and rebirth.

Vetus Testamentum started its life in 1951, in the aftermath of the Second World War, with the express objective of bridging the divides that at that time had torn the scholarly world apart. It has served that purpose well, functioning as a platform for high-level research on the Hebrew Bible/Old Testament across Europe and North America.

With ever increasing participation of scholars in other countries around the globe the journal is well positioned to face new challenges arising from developments both internal and external to the field of biblical studies.

The present issue marks the seventieth year of the journal with an unprecedented formula. Each member of the editorial board has written an essay reflecting her or his present research. The papers have been peer-reviewed and revised as necessary. We hope readers will find this special, collective issue a fitting way of celebrating VT's seventieth birthday, and of renewing its commitment to publishing the best research worldwide in the study of the Hebrew Bible/Old Testament.

Jan Joosten and Steve McKenzie 